\title{
The Lithuanian Metrica and the Lithuanian Nobility at the End of the Eighteenth Century
}

\section{Zigmantas KIAUPA}

At the end of the eighteenth century the Polish-Lithuanian nobility had far more pressing matters to consider than the fate of the Lithuanian Metrica. In the Polish-Lithuanian Commonwealth (also called the Republic of the Two Nations), radical political and social reforms were introduced at the very time the Republic, encompassed by the aggressive interests of Russia, Prussia and Austria, was about to lose its independence. Nevertheless, we decided to investigate this particular archival theme because every detail is important, if we are to understand the political situation at the end of the eighteenth century. We shall explore the attitudes of Lithuanian noblemen towards the Metrica - the state archive of the Grand Duchy of Lithuania, which was kept in the care of the highest state officials, namely the Chancellor and Vice-Chancellor. This should help us to understand better Lithuanian noble mentality and reveal how the elite regarded the state. In addition, we hope to throw some light on matters connected with the Metrica which have not been examined in detail so far.

The main sources on which we shall draw are the instructions given by local noble dietines (sejmiki, seimeliai) to their representative in the Commonwealth's Seim. These are preserved in the volumes of District Court Records which have been studied several times. Scholars have also used the parts of these records which refer to the Metrica. In his studies of Polish-Lithuanian relations after the Union of Lublin (1569) and the situation in Lithuania during the period of the Four Years' Seim (1788-92), Adolfas Šapoka investigated the district dietines' instructions (1788-90) in detail and found that the problems of the Metrica were discussed frequently ${ }^{1}$. Šapoka's transcripts of the Instructions also survive ${ }^{2}$. Mečislovas Jučas also noted how discussion concerning the Metrica appeared in the Instructions ${ }^{3}$. Both

${ }^{1}$ A. Šapoka, Lietuva ir Lenkija po 1569 metu unijos, Kaunas,1938, 282, 292; idem, Lietuva reformu seimo metu. Iki $1791 \mathrm{~m}$. gegužès 3 d. konstitucijos, Kaunas,1936, 120-185 [Typescript in MAB, f.233 - A. Šapoka, b. 115; two other copies, ibid., f. 233 - A. Šapoka, b. 116, 117].

${ }^{2}$ Those of 1788: MAB, f. 233, b. 125; and of 1790: MAB, f. 233, b. 126.

${ }^{3} \mathrm{M}$. Jučas, XVIII a. socialinès ir politinès problemos Lietuvos pavietu seimeliuose, LIM, 1973, 26. 
scholars discussed the noble interest in this matter only in passing and the question became submerged in the wider context of the Grand Duchy's politics in the later eighteenth century.

We shall use well-known material and a newly discovered source to analyse how Lithuanian noblemen became interested in the fate of the Metrica, and how such interest affected the form of the Archive as it now survives.

It is known that the Metrica was taken from Vilnius to Warsaw in the $1750 \mathrm{~s}^{4}$. However, Lithuanian nobles did not forget about the records which they regarded as belonging to them and being preserved for their use. Such a viewpoint was expressed most clearly by the Dietine of Rechitsa in 1788 which stated that the Lithuanian Metrica was "a collection of noble privileges and charters" 5 . The nobles were informed that the Metrica was being put in order, described and registered. Moreover the Grand Duke, Stanisław August, would report on the progress of this work before the dietines of 1788 . During that year the dietines of several districts (Kaunas, Mozyr, Novgorodok, Pinsk, Rechitsa and Upytè), proposed votes of thanks for the Grand Duke for putting the Metrica in order ${ }^{6}$. The nobles appreciated the great amount of work put in by the Metricant (Keeper of the Metrica), Grzegorz Kaczanowski, during the re-ordering of the Archive and offered to reward him by making him the equal in function and stipend of the Keeper of the Metrica of the Polish Crown. This was proposed by the dietines of Grodno, Pinsk and Polotsk ${ }^{7}$. The Upyte Dietine of 1788 also reported the Grand Duke had appointed Kaczanowksi to deal with the Lithuanian Metrica ${ }^{8}$. However, was the Grand Duke's interest in the Metrica the only reason for the dietines' concern? There were more serious reasons for this.

First of all, the importance of local dietine and the state archives was well appreciated. As early as 1744 and 1748 the Kaunas dietine announced: "Gentlemen, members of the Diet, Your Graces should spare no effort to require His Royal Majesty to intercede with the Russian Court for the return of the ancient records of the Supreme Tribunal of the Grand Duchy of Lithuania, the Metrica and the regional and urban records of certain województwa and powiaty, which are needed by the whole Grand Duchy and were seized by the Muscovite army during hostilities and taken off to Smolensk and Kiev where they are still held "9.

${ }^{4}$ S. Ptashitskii, Opisanie knig $i$ aktov Litovskoi Metriki, St Petersburg, 1887, 12; The "Lithuanian Metrica" in Moscow and Warsaw: Reconstructing the Archives of the Grand Duchy of Lithuania. Including an annotated edition of the 1887 Inventory compiled by Stanisław Ptaszycki, ed. P. Kennedy Grimsted and I. Sułkowska-Kurasiowa, Cambridge MA, 1984, 14.

5 "za uporządkowanie i opatrzenie na długą konserwę kosztem JKM archivum metryki litewskiej, jako składu nadan i priwilejów szlacheckich", MAB, f. 233, b.125, f. 26.

${ }^{6}$ Ibid., f. 26, 46; A. Šapoka, Lietuva reformu..., 137-139, 156, 172, 175, 178.

${ }^{7}$ MAB, f. 233 B.125, f. 20; A. Šapoka, Lietuva reformu..., 153, 172.

${ }^{8}$ A. Šapoka, Lietuva reformu..., 139. 
In 1790 the Žemaitijan Diet approved the demands of its Kaunas counterpart, asking the representatives of the Diet to "seize the present opportunity to remind their excellencies the Prussian and Muscovite ministers of the need to return our records which have long been kept in Prussia and Muscovy"10. The nobles were even more anxious about the predicament of local records. The Lida dietine of 1788 described the pitiful condition of the local archive in some detail. In order to protect their own records from destruction or theft, many nobles had already transferred their archives to Vilnius Cathedral for safe-keeping. The members of the Lida dietine raise the alarm over the state of neglect into which the episcopal archive had fallen ${ }^{11}$. In 1790 the Minsk dietine noted that the old archives had disappeared and that the ruszczyzna (Ruthenian texts copied in Cyrillic) was becoming more and more difficult to decipher. District representatives were asked to endeavour to found a Commission to sort out, translate and transcribe the documents ${ }^{12}$.

The other reason for noble interest in the Metrica was the increasing use to which it was being put in everyday life. This is not the place to go into this subject in depth, but one example may suffice to illustrate the increase in recourse to the record. Certain magnate families within the Grand Duchy such as the Chreptowiczes copied material relevant to their needs from the Metrica - in this case in the $1780 \mathrm{~s}^{13}$. Such transcriptions were made frequently during the second half of the eighteenth century during the reigns of August III and Stanisław August ${ }^{14}$. Evidence of resort to the records is given by the signatures of readers at the end of each volume. Most of these signatures date from the second half of the eighteenth century.

All this activity took place despite the trials and tribulations endured by the citizens of the Grand Duchy. Difficulties are noted in the Instructions emanating from the dietines: the great distance from Warsaw where the Metrica was stored, the cost in time and money of gaining access to the record. The Grodno dietine expressed such dissatisfaction most eloquently in 1790: "the most perilous conditions face those estates which cannot find those documents they need at

9 "[...] Akta dawne trybunału głownego WKL metryki, także ziemskie, grodzkie niektórych województw i powiatów durante hostilitate przez wojska moskiewskie z Wilna zabrane w Smolensku (i Kijowie) dotąd degentia jako są iniuralis i całemu WKL potrzebne, aby interpositione JKM pana naszego miłosciowego do dworu rosyjskiego rekuperowane były mogli ichm. pp. posłowie instabunt" - 1744 Kaunas Powiat Castle Court Records, MS: LVIA, Senieji Aktai, b. 13694, f. 119"; and the 1748 Kaunas Powiat Castle Court Records, b. 13696, f. 212v; M. Jučas, op. cit., 26.

10 “[...] Uzyją j. w. posłowie terazniejszej sposobności dopomnienia się u j. w. ministrów pruskiego i moskiewskiego o zwrot dokumentów naszych jednych za granicą pruską, drugich w moskiewskim od dawna zaległych" - MS: MAB, f.233, b.126, f. 172.

${ }_{11}^{11}$ Ibid., b.125, f. $31^{\vee}$-32; A. Šapoka, Lietuva reformu..., 124

${ }^{12} \mathrm{MAB}, \mathrm{f} .233$, b.125, f.126, 85; A. Šapoka, Lietuva reformu..., 455

${ }^{13}$ Warsaw, AGAD, Archiwum Tyzenhauzów, B-4/39.

14 Warsaw, AGAD, Zbiór Dokumentów papierowych Nos. 2115, 2116, 3918-3921, $3955,4097$. 
hand to defend them from any accident. The whole province of Lithuania faces such misfortune because the testamentary records of the Metrica, the Lithuanian Archive and all transactions referring to inheritance of property since the expulsion of the Jesuits and legal cases connected with the Polish Crown have fallen into Crown hands and the control of citizens of the Polish Crown. The citizen who manages to avoid unpleasant expense while trying to obtain the documents he needs is a rare bird indeed ${ }^{15}$.

Such conditions did not satisfy the nobles of the Grand Duchy, and the district dietines formulated revisions to the way the Metrica were kept. The first proposition was that the Metricant be provided with material aid to re-order the records and make them more available. In 1788 the dietines of Kaunas, Mozyr, Novgorodok and Pinsk offered to provide extra resources for continuing the registering of the Metrica ${ }^{16}$. In 1788 the dietine of the Vilnius district, and in 1790 that of Lida, made a concrete proposal: to register every document in the Metrica, catalogue these descriptions and send the information to district chanceries ${ }^{17}$.

Most district dietines suggested a more radical solution - the return of the Metrica to Lithuania. The earliest such demand was made in the 1786 instructions to the dietines of Upyte and Trakai ${ }^{18}$. The same demand was made by these dietines in 1788 and this time the motion was seconded by the dietines of Grodno, Lida, Mozyr, Rechitsa and Smolensk ${ }^{19}$. The dietines of Grodno and Lida, together with Kaunas repeated the demand for the return of the Metrica in $1790^{20}$.

Proposals were made to transfer the Metrica to Vilnius (four instructions), to Grodno (two instructions), to Vilnius or Grodno (one instruction), to an unspecified town in the Grand Duchy which was understood to be Vilnius, the capital city (five instructions).

One of the reasons for the return of the Metrica to Lithuania has been noted already, namely the difficulties which arose in access

15 "Najniebezpieczniejszy jest stan tych dóbr, które na obronę wszelkich przypadków in fundo nie znajdują służących sobie dokumentów. Właśnie tej niedoli doswiadcza cała prowincja litewska, której dziedziczne dokumenta metryki archiwum litewskie i wszelkie na dobra pojezuickie dziedziczne tranzakcje i processa prawne w przypadku do Korony uwiezione na zawsze tam wklęsły i pod rząd obywatelów koronnych oddane zostali. Rzadki obywatel nie doznał przykrości większego expensu w staraniu się i wyjmowaniu potrzebnych dokumentów", MAB, f.233, b.126, f.26.

${ }^{16}$ A. Śapoka, Lietuva reformu..., 138, 156, 172, 175

${ }^{17} \mathrm{MAB}$, f. 233 , b.125, f. $35^{\mathrm{v}}$; b. 126 , f. 64 .

${ }^{18} \mathrm{M}$. Jučas, XVIII a. socialinès..., 26. Here the date of the Upyte dietine is given by mistake as 1785. In that year no dietines were convoked. Cf. Instruction of the Upyte Dietine of 1786, in Upytes pavieto žemès teismo aktı knyga, LVIA, Senieji aktai, b. 15729, f. $532 \mathrm{v}$.

${ }^{19} \mathrm{MAB}, \mathrm{f} .233$, b.125, f. $6,19,26,32,45$; Upytés pavieto žemés teismo aktu knyga (1788), MS. LVIA, Senieji aktai, b. 15281, f. 448 ${ }^{v}$. A. Sapoka, Lietuva reformu..., 125, 133, 138, 147 , 175,178 .

${ }^{20} \mathrm{MAB}$, f.233, b.126, f. 26, 49, 64; A. Šapoka, Lietuva reformu..., 125, 133, 138, 147 , $175,178$. 
to records stored so far from the Grand Duchy. In almost all cases the demand for the return of the Metrica was accompanied by the request to transfer the Assessor's Court of the Grand Duchy to Lithuania. The latter demand was also based on the distance of Warsaw, home of that Court, from Lithuania.

However, the Grodno dietine's instruction also mentions that the Metrica had fallen into Polish hands. Šapoka asserts that the defence of Lithuanian independence within the Commonwealth was not a matter of urgent concern in the dietine instructions of 1788 and $1790^{21}$. He notes that such a danger was not perceived, and the particular reforms of the Four Years' Seim were not expected. Even during such a peaceful time the tendencies to resist the Commonwealth and the closer institutional integration of Poland and Lithuania were obvious: there were demands to maintain the separate state organs and central courts of the Grand Duchy. The main concern over the housing of the Metrica is perfectly consistent with a whole gamut of desires and demands to preserve Lithuanian statehood within the Commonwealth.

The question arises as to what was the response to the proposals and demands, voiced by the district dietines between 1786 and 1790. This matter has not been fully investigated, but we may make some observations and even conclusions. Following the victory of the Targowica Confederation (August 1792), the General Confederation of the Grand Duchy of Lithuania issued a series of universal proclamations concerning the archives which had been removed from Lithuania. The Decree of August 14, 1792 sought to separate the Lithuanian Metrica from the records of the Polish Crown and transfer them to Grodno by September $151792^{22}$. The Decree of September 23, 1792 required the Lithuanian Metricant to bring the Metrica to Vilnius and deposit it in the Jesuit house next to the church of St Casimir ${ }^{23}$.

The requirements of the latter decree were implemented but the extent to which they were enforced is unknown. The accounts ledgers of the Vilnius magistracy for $1794-5$ record that during the period January $9-18$, monies were expended for making 50 boxes to transfer the Lithuanian Metrica from Warsaw to St Petersburg ${ }^{24}$. The door of the Metricant's lodge was repaired too. Although the rubric of the accounts states that the Metrica was transferred from Warsaw, it is clear that a large part of it at least was already in Vilnius and that,

${ }^{21}$ A. Šapoka, Lietuva ir Lenkija..., 282, 292; idem, Lietuva reformu..., 185, 470-471.

${ }^{2}$ Zbiór wszystkich druków konfederacji targowickiej i wileńskiej, Warszawa, 1792, 242 244. A copy of the decree is bound in a volume held by the Lithuanian National M. Mažvydas Library: Księga obejmująca dawniejsze różne wiadomości tak duchowne, jako i cywilne z r. 1783-1794, f. 58.

${ }^{23}$ Ksiegga obejmujaca..., f. 69.

${ }^{24}$ LVIA, f. 458 , ap.1, b. 370 , f. 54. 
according to an ukaz issued by the Russian authorities, it was being prepared for transfer to the imperial capital. The fact that the Metrica had been in Vilnius is corroborated by the report which the Metricant Kaczanowksi made to the head of the Russian Administration in Lithuania, Prince Nikolai Repnin, in the aftermath of the Uprising of 1794 and the shooting of the political leaders of the Commonwealth. In autumn 1974 Kaczanowski reported that "during this past confusion", he had "deposited a large part of the documents which make up the Lithuanian Metrica in St Casmir's in Vilnius, in accordance with the instructions of the then government" ${ }^{25}$. Therefore, we may conclude that the Lithuanian nobles succeeded in implementing at least part of their plan to return the Metrica to Lithuania. Following the destruction of the Republic of the Two Nations in 1795, the Lithuanian Metrica, or at least a large part of it, was transferred home to Vilnius and from there, rather than from Warsaw, it was carried off into exile in the alien city of St Petersburg. 